\title{
Notes on Pachyphyllinae (Vandoideae, Orchidaceae) with a description of a new genus
}

\author{
Marta Kolanowska • Dariusz L. Szlachetko
}

Received: 10 October 2013/Accepted: 21 March 2014/Published online: 22 April 2014

(c) The Author(s) 2014. This article is published with open access at Springerlink.com

\begin{abstract}
The Neotropical subtribe Pachyphyllinae comprises orchids distributed mainly along the Andes and characterized by the monopodial type of growth. The systematic position of this taxon within Orchidaceae and its generic composition was intensively discussed, but so far no comprehensive morphological study on the group was conducted. In this paper the morphological descriptions of all genera included in Pachyphyllinae are provided and the key to their identification is presented. In addition, the taxonomic position of Raycadenco is discussed. The research revealed the existence of two distinctive species which were classified until now within Pachyphyllum or Fernandezia. Since neither the flower morphology of those two species nor the gynostemium structure fulfils the concept of any known orchid taxon, the new genus is described here under the name Valdiviesoa. The two representatives of the new taxon are illustrated and the photographs of the plants are provided. The information about their distribution and ecology are provided. The morphological characters of all Pachyphyllinae representatives are compared.
\end{abstract}

Keywords Andes - Morphologic inferences $\cdot$ New genus $\cdot$ Neotropics $\cdot$ Taxonomy $\cdot$ Valdiviesoa

\section{Introduction}

The subtribe Pachyphyllinae comprises small to mediumsized epiphytic, lithophytic or terrestrial orchids with tiny

M. Kolanowska $(\varangle) \cdot$ D. L. Szlachetko

Department of Plant Taxonomy and Nature Conservation,

University of Gdańsk, ul. Wita Stwosza 59, 80-308 Gdańsk,

Poland

e-mail: martakolanowska@wp.pl or small, inconspicuous or quite showy, dull or brightly colored flowers. The unique character of all genera ever included to this group is monopodial growth. Pachyphyllinae is one of the most problematic orchid taxon and its systematic position within Orchidaceae was variously recognized by taxonomists (e.g. Dressler and Dodson 1960; Dressler 1971, 1981; Chase et al. 2003). Pachyphyllinae (originally Pachyphylleae) was proposed first by Pfitzer (1887) based on the large, petaloid clinandrium and fleshy, short leaves observed in Centropetalum Lindl., Nasonia Lindl. and Pachyphyllum Kunth. The author placed the newly created taxon together with Aerideae within Sarcanthinae (originally Sarcantheae). Unfortunately, the nomenclatural problem with this classification system was that over 50 years earlier Lindley applied the generic name Sarcanthus twice-in 1824 with Epidendrum praemorsum Roxb. as a type species and in 1826 while describing Sarcanthus rostratus Lindl. (Lindley 1824, 1826). Hereby, the name Sarcanthinae as an illegitimate was replaced with Aeridinae (Garay 1972).

Schlechter (1915) accepted Pfitzer's Pachyphyllinae, but proposed a different solution, placing Dichaeinae and Pachyphyllinae with "Unterreihe II. Monopodiales", i.e. with Sarcanthinae. While Dressler and Dodson (1960) classified Pachyphyllinae within Epidendreae (Orchidoideae), the first author changed his concept 10 years later (Dressler 1971) elevating the taxon to the tribal rank. Second reconsideration of orchid classification system was presented by Dressler in early 1980s and he proposed to include Pachyphyllinae (as the representative of vandoid orchids) into the tribe Cymbidieae (Dressler 1981). The subtribe was classified within Vandoideae also by Senghas (1995) who, however, considered Pachyphyllinae as members of the tribe Oncidieae. The different approach was proposed by Szlachetko (1995) 
Table 1 Comparative morphology of Centropetalum, Nasonia and Fernandezia

\begin{tabular}{|c|c|c|c|}
\hline Character & Centropetalum & Nasonia & Fernandezia \\
\hline Pseudobulbs & Absent & Absent & Absent \\
\hline Leaves & Distichous, fleshy & Distichous, fleshy & Distichous, fleshy \\
\hline Inflorescence & $\begin{array}{l}\text { Lateral, from the upper } \\
\text { part of the plant }\end{array}$ & $\begin{array}{l}\text { Lateral, from the upper } \\
\text { part of the plant }\end{array}$ & $\begin{array}{l}\text { Lateral, from the upper } \\
\text { part of the plant }\end{array}$ \\
\hline Lip & Much larger than tepals & $\begin{array}{l}\text { Smaller or slightly larger } \\
\text { than tepals }\end{array}$ & Much larger than tepals \\
\hline Lateral sepals & Free & Partially connate or free & Free \\
\hline $\begin{array}{l}\text { Gynostemium- } \\
\text { column part }\end{array}$ & $\begin{array}{l}\text { Slender, erect, broadly } \\
\text { winged }\end{array}$ & $\begin{array}{l}\text { Slender, erect, broadly } \\
\text { winged }\end{array}$ & $\begin{array}{l}\text { Slender, erect, broadly } \\
\text { winged }\end{array}$ \\
\hline Column foot & Absent & Absent & Absent \\
\hline Anther & $\begin{array}{l}\text { Ventral, incumbent, } \\
\text { operculate, } \\
\text { dorsiventrally } \\
\text { compressed }\end{array}$ & $\begin{array}{l}\text { Ventral, incumbent, } \\
\text { operculate, } \\
\text { dorsiventrally } \\
\text { compressed }\end{array}$ & $\begin{array}{l}\text { Ventral, incumbent, } \\
\text { operculate, } \\
\text { dorsiventrally } \\
\text { compressed }\end{array}$ \\
\hline Caudiculae & Filiform & Filiform & Filiform \\
\hline Polliniarium & With two tegulae & With single tegula & With two tegulae \\
\hline Clinandrium & Irregularly denticulate & Entire & Irregularly denticulate \\
\hline
\end{tabular}

Table 2 Comparative morphology of Pachyphyllum and Orchidotypus

\begin{tabular}{|c|c|c|}
\hline Character & Pachyphyllum & Orchidotypus \\
\hline Leaves & Fleshy, distichous & Fleshy, distichous \\
\hline Inflorescence & Lateral, sparsely branched, 1-5-flowered & Lateral, simple, 1-3-flowered \\
\hline Tepals & Free to the base & Connate forming a prominent tube \\
\hline Lip & Simple to slightly 3 -lobed, callus a pair of digitate projections & $\begin{array}{l}\text { Petaloid, with claw united to the perianth tube, with a pair } \\
\text { of rounded calli on each side below the disk base }\end{array}$ \\
\hline Gynostemium & Sessile, gently arched, delicate & Sessile, gently arched, delicate \\
\hline Column part & $\begin{array}{l}3 \text { times longer than anther, broadly winged, wings thin, close one to } \\
\text { another or even touching each other in front of the gynostemium }\end{array}$ & Twice as long as anther, broadly winged \\
\hline Column foot & Obscure & Absent \\
\hline Anther & $\begin{array}{l}\text { Ventral, incumbent, operculate, slightly dorsiventrally compressed, } \\
\text { ellipsoid-obovoid, obscurely 2-chambered }\end{array}$ & $\begin{array}{l}\text { Ventral, incumbent, motile, dorsiventrally compressed, } \\
\text { ellipsoid-cordate, obscurely 2-chambered }\end{array}$ \\
\hline Pollinia & $\begin{array}{l}\text { 2, slightly dorsiventrally compressed, obliquely obovoid, rather } \\
\text { hard }\end{array}$ & $\begin{array}{l}\text { 2, slightly dorsiventrally compressed, obovoid to clavate, } \\
\text { rather hard }\end{array}$ \\
\hline Caudiculae & Amorphous, sticky & Amorphous, sticky \\
\hline Clinandrium & $\begin{array}{l}\text { Well-developed, forming a very high collar hiding completely the } \\
\text { anther, entire on margin }\end{array}$ & $\begin{array}{l}\text { Well-developed, forming a very high collar hiding } \\
\text { completely the anther, entire or irregularly denticulate } \\
\text { on margin }\end{array}$ \\
\hline Stigma & Elliptic to transversely elliptic, deeply concave & Elliptic, concave \\
\hline Viscidium & Single, very small, elliptic-obovate, thin, lamellate & Single, relatively large, elliptic-obovate, thin, lamellate \\
\hline Rostellum & $\begin{array}{l}\text { Very short; remnant very shortly digitate, obscurely bilobed at the } \\
\text { apex }\end{array}$ & Very short; remnant very shortly bilobed at the apex \\
\hline Tegula & Single, oblong, small, thin, lamellate & Single, linear, very small, thin, lamellate \\
\hline
\end{tabular}

who based mainly on the gynostemium morphology placed Pachyphyllinae in Dichaeeae, within subfamily Vandoideae. The molecular studies (Chase et al. 2003) indicate the close relation between Pachyphyllinae and oncidioid orchids and its position within Cymbidieae (Epidendroideae sensu lato).

As mentioned before also the generic delimitation within Pachyphyllinae was a topic of discussion between taxonomists. Schlechter (1915) recognized Pachyphyllum, Nasonia and Centropetalum as the members of the subtribe and he considered Orchidotypus Kraenzl. synonymous with Pachyphyllum. Except Senghas (1995) and Szlachetko and Mytnik-Ejsmont (2009), the broad concept of the latter genus was accepted by the subsequent researchers. Dressler and Dodson (1960) included species of Fernandezia in Centropetalum, but the first author accepted Fernandezia 
A
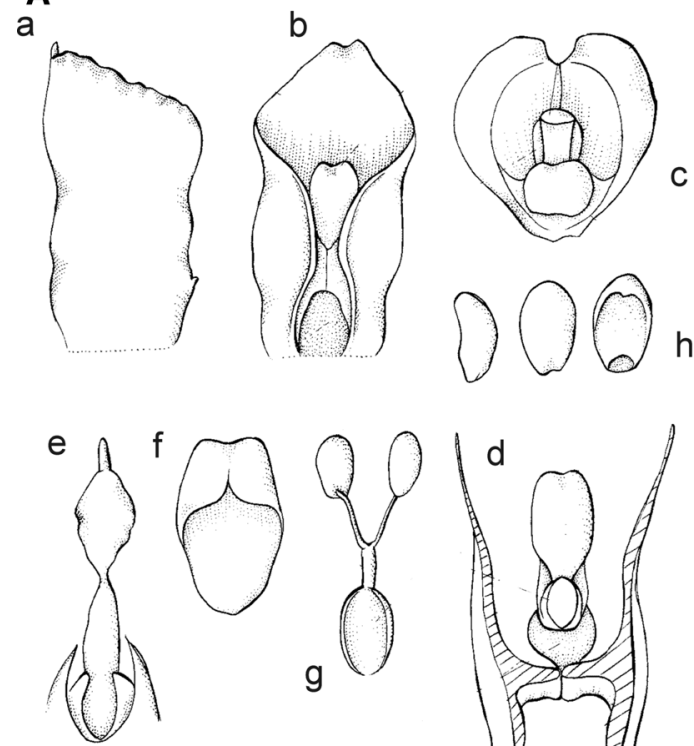
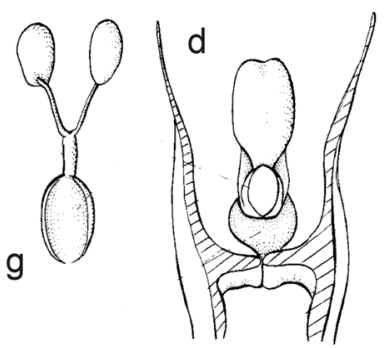

B
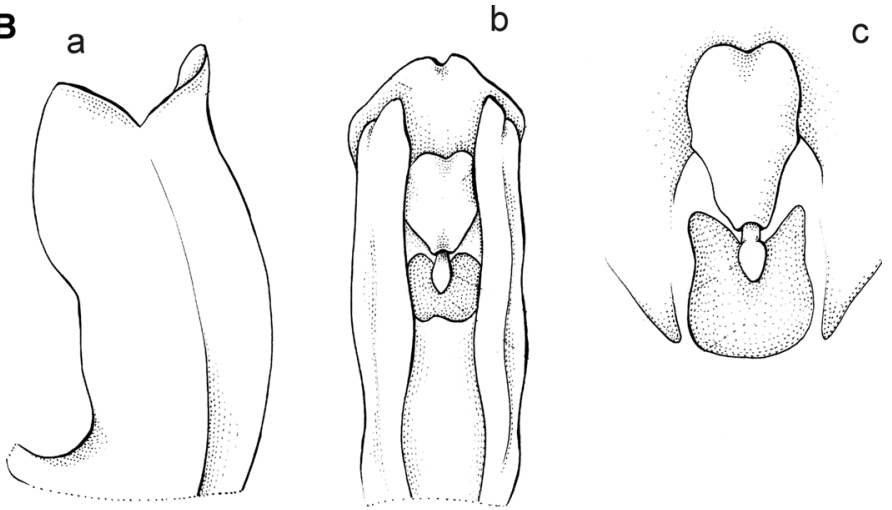
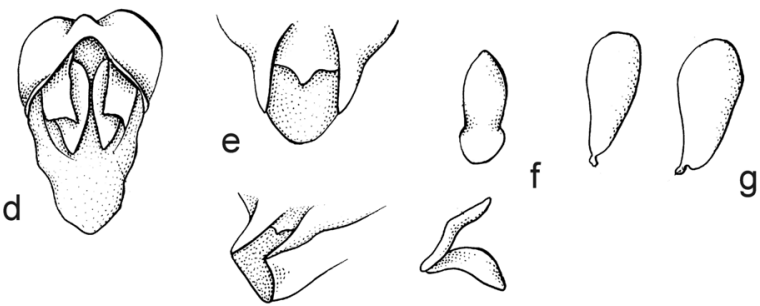

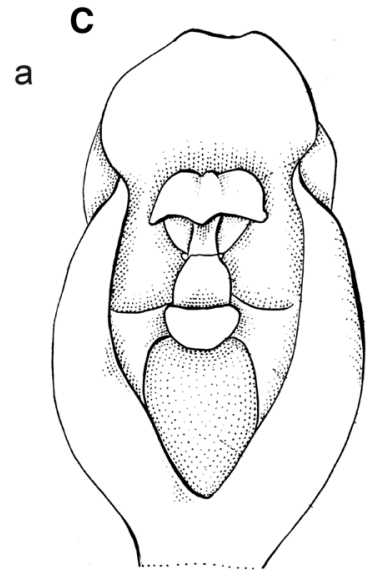

Fig. 1 Gynostemium structure of A Fernandezia ionanthera (a Gynostemium, side view. $b$ Gynostemium, bottom view. $c$ Gynostemium, front view. $d$ Gynostemium, front view, wings partially removed. $e$ Rostellum remnant. $f$ Anther, back view. $g$ Pollinarium. $h$ Pollinia, various views (L.H-N 3985, AAU). B Pachyphyllum pastii ( $a$ Gynostemium, side view. $b$ Gynostemium, bottom view. $c$ Gynostemium,

as a correct name for those plants in 1981. The most recent molecular studies on oncidioid orchids (Chase and Whitten 2011; Neubig et al. 2012) resulted in synonymization of Pachyphyllum under Fernandezia. Chase and Whitten (2011) included in this genus also monotypic Raycadenco which was not considered as member of Pachyphyllinae ever before.

In this paper the results of the morphological studies on Pachyphyllinae combined with molecular outcomes already published are presented. bottom view, wings spread. $d$ Anther, back view. $e$ Rostellum remnant. $f$ Tegula and viscidium, various views. $g$ Pollinia, various views (L.H-N 6486, AAU). C Orchidotypus bryophytus (a Gynostemium, bottom view. $b$ Gynostemium, side view. $c$ Pollinia, various views (Heidelberg BG O-636360, HEID). Reproduced from Szlachetko and Mytnik-Ejsmont (2009)

\section{Materials and methods}

Dried herbarium specimens as well as flowers preserved in liquid of species considered as members of Pachyphyllinae in any previous research were examined. Herbaria acronyms are cited in these papers according to Index Herbariorum (Thiers, continuously updated).

The plant material was studied in or borrowed from the following herbaria AMES, B, BM, COL, HBG, HEID, K, $\mathrm{P}, \mathrm{W}$. The specimens were examined according to the 
standard procedures. Each studied specimen was photographed and the data from the label were taken. The shape of the leaf blade and form of the leaf base were studied first. The perianth segments as well as the form of ovary and floral bracts were studied under a stereoscopic microscope. The floral elements, including the gynostemium, their shape, structure and surface were examined after softened flowers in the boiling water. Comparison of the studied material with the designated type specimens and protologues assured the correctness of identifications. A total of about 300 herbarium sheets and specimens preserved in alcohol were revised. Field studies have been conducted during expeditions to Colombia, Ecuador and Peru in the years 2005-2012.

\section{Results}

The analysis of the morphology of three recently combined genera, Fernandezia, Pachyphyllum and Raycadenco indicated the generic distinctiveness of each of them. Two genera, Centropetalum Lindl. and Nasonia Lindl., recognized in several previous studies (Pfitzer 1887; Schlechter 1915; Dressler and Dodson 1960; Schweinfurth 1961) were found to be synonymous with Fernandezia (Table 1). The first genus was described by Lindley (1838) based on i.a. its lip larger than free sepals while the second one was found different by the same author (Lindley 1844) in its smaller lip and partially connate lateral sepals. However, in 1846 he added a new species to Nasonia, N. sanguinea which was not in accordance with the previously provided floral characters of the genus, but as its nominal species, $N$. punctata, it was characterized by the presence of a single tegula. In 1923 Kraenzlin transferred known Nasonia species to Centropetalum and the latter was synonymized with Fernandezia by Garay and Dunsterville (1972).
The comparison of the three genera is presented in Table 1 . Species of Centropetalum and Fernandezia are undistinguishable in their morphological characters; thus we agree that the former should be treated as a synonym with Fernandezia. The observed morphological differences are not sufficient to consider Nasonia and Fernandezia as separated genera either, however, the dissimilarities should be emphasized by the division of the latter genus into two subgenera as proposed by Garay and Dunsterville (1972).

The morphological characters of Pachyphyllum and Orchidotypus, which are usually considered as synonymous (e.g. Schlechter 1915; Schweinfurth 1961; Dressler 2003; Christenson 2008), were studied and their comparison is presented in Table 2. Based on the numerous differences observed both in perianth segments form as well as in the gynostemium structure (Fig. 1), we believe that those taxa should be treated separately, as proposed by Senghas (1995).

\section{Discussion}

As mentioned before, Chase and Whitten (2011) transferred all Pachyphyllum, Orchidotypus and Raycadenco species to Fernandezia based on the molecular studies; however, the outcomes from the genetic research are difficult to evaluate. The phylogenetic tree presented by Chase (2009) includes just two Fernandezia s.str. species, one representative of Pachyphyllum s.str. and Raycadenco. The latter is sister to the pair Fernandezia-Pachyphyllum, which are sisters to each other. On the other hand, the tree provided by Neubig et al. (2012; Fig. 2) contains 17 taxa of Pachyphyllineae (sensu Chase and Whitten 2011), seven of which remains unidentified on the species level. Also here, Raycadenco is sister to all other Pachyphyllineae taxa. According to Neubig et al. (2012), Fernandezia and

Fig. 2 Fragment of single maximum likelihood tree resulting from analysis of the combined five-region data (Neubig et al. 2012)

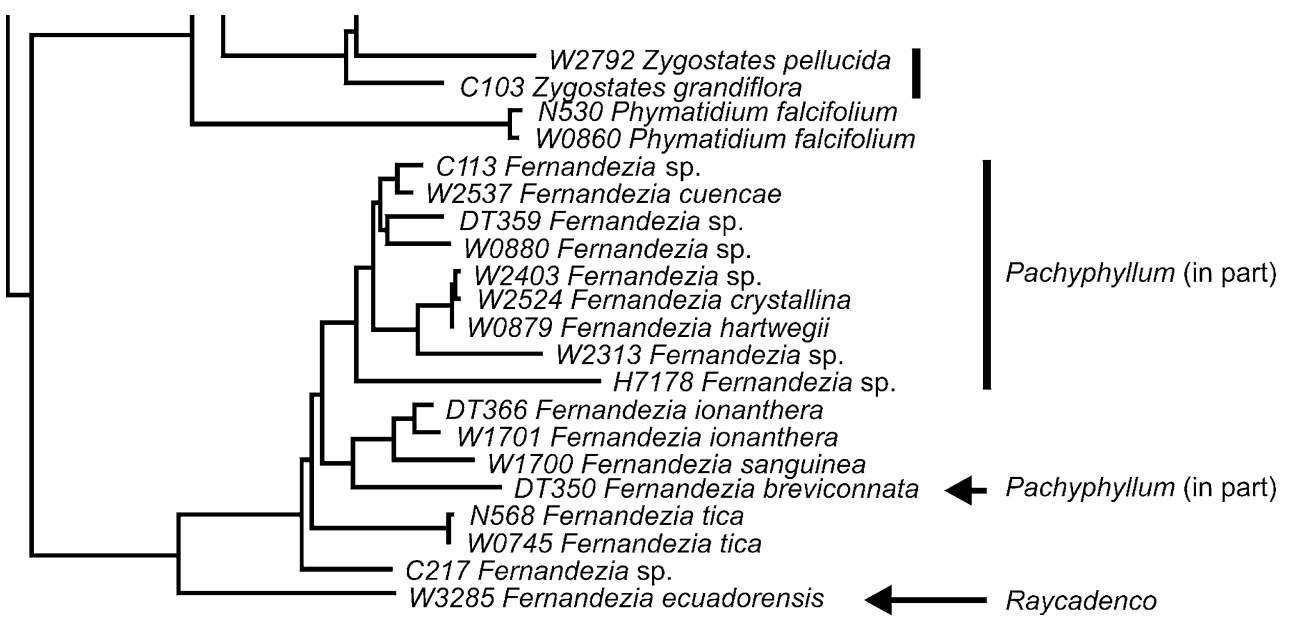


Fig. 3 Fernandezia

breviconnata. a Dissected perianth (redrawn from Schlechter 1929). b Plant (photo: Senghas, SOF)
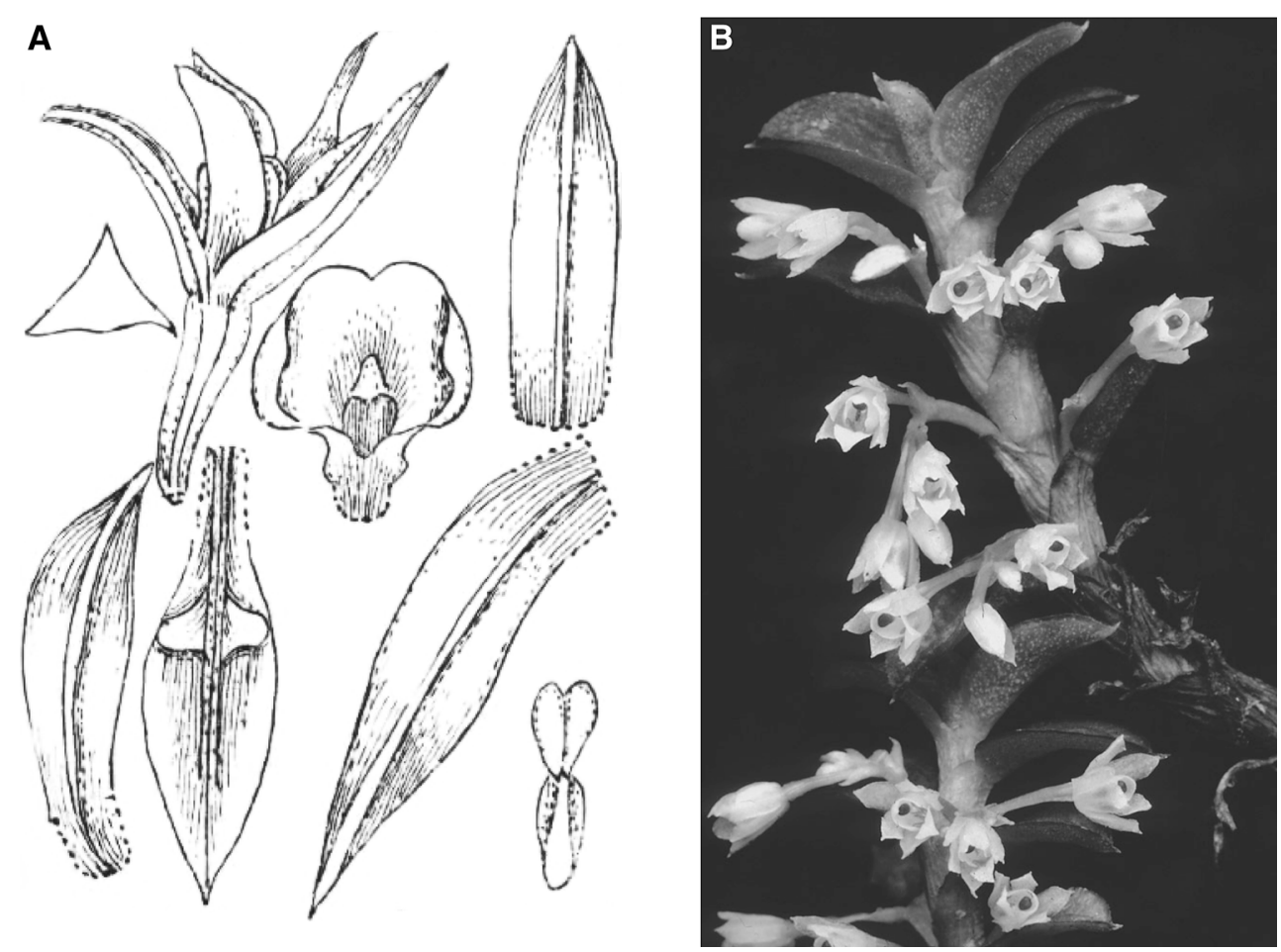

Fig. 4 Gynostemium structure of Raycadenco ecuadorensis. a Gynostemium, bottom view, anther removed.

$b$ Gynostemium, side view. $c$ Pollinia. $d$ Anther. $e$ Pollinarium $(a-c$ Heidelberg BG O-838, HIED; $d-e$ redrawn from Dodson 1989)

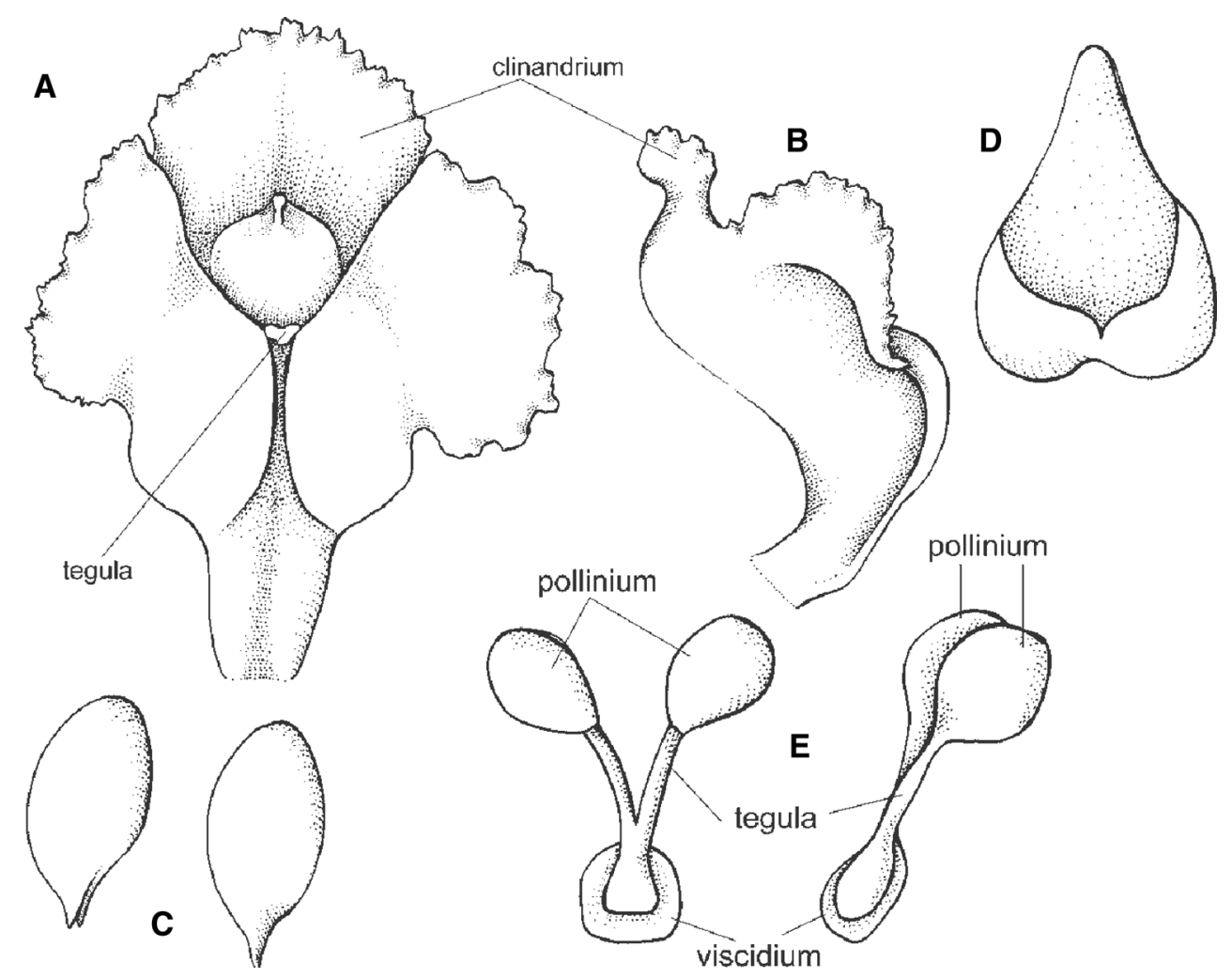


Pachyphyllum are distinguished on the basis of flower size and color. Pachyphyllum (including Orchidotypus) has tiny, white or yellow flowers and its pollinators are unknown, whereas Fernandezia s.str. has larger flowers that are bright red or orange and are hummingbird pollinated. In our opinion this differentiation is an obvious simplification, what we tried to demonstrate above. The measurements of the perianth segments of these genera overlap frequently and there is no demarcation line in this respect. The flowers of $F$. breviconnata are white or whitish, rather small (Fig. 3).

All Pachyphyllum, Orchidotypus and Fernandezia, as well as Raycadenco are small, monopodial plants (up to $30 \mathrm{~cm}$ tall), with lateral, 1- or few-flowered inflorescences. Unlike in former genera, the tegula of Raycadenco is Y-shaped (vs filiform to oblong) and its lip is 4-lobed (vs entire) with a complicated callus, similar to Oncidium and allied taxa.

Chase and Whitten (2011) stated that Raycadenco exhibits the suite of traits associated with oil-collecting bees' pollination. According to the authors, the floral structure of Pachyphyllum, Fernandezia and Raycadenco, "outside of the gross modifications for different pollinators, is otherwise similar; they all have a pair of column wings and/or a dorsal hood", what is in conflict with our observations. Chase and Whitten (2011) postulated that Raycadenco could be maintained as a separate genus due to its sister position to the rest of the clade, but given that its habit and floral morphology agree with that of Fernandezia/Pachyphyllum in technical detail, the authors decided to include it in Fernandezia, and thereby, decrease the redundancy/increase information content of the classification. Again, we cannot accept this "technical" solution, as all of these four genera differ clearly one from another in the floral characters and their only common, but not unique feature is a monopodial type of growth. The amalgamation of all the taxa in question under common name Fernandezia surely does not improve the information content of the classification, but increase the chaos.

Fig. 5 Gynostemium structure of Lockhartia chocoensis. $a$ Gynostemium, bottom view. $b$ Gynostemium, side view. $c$ Rostellum remnant, front view. $d$ Anther, back view. $e$ Pollinia, various views. $f$ Tegula and viscidium, view from above (Heidelberg BG O-65080, HEID)

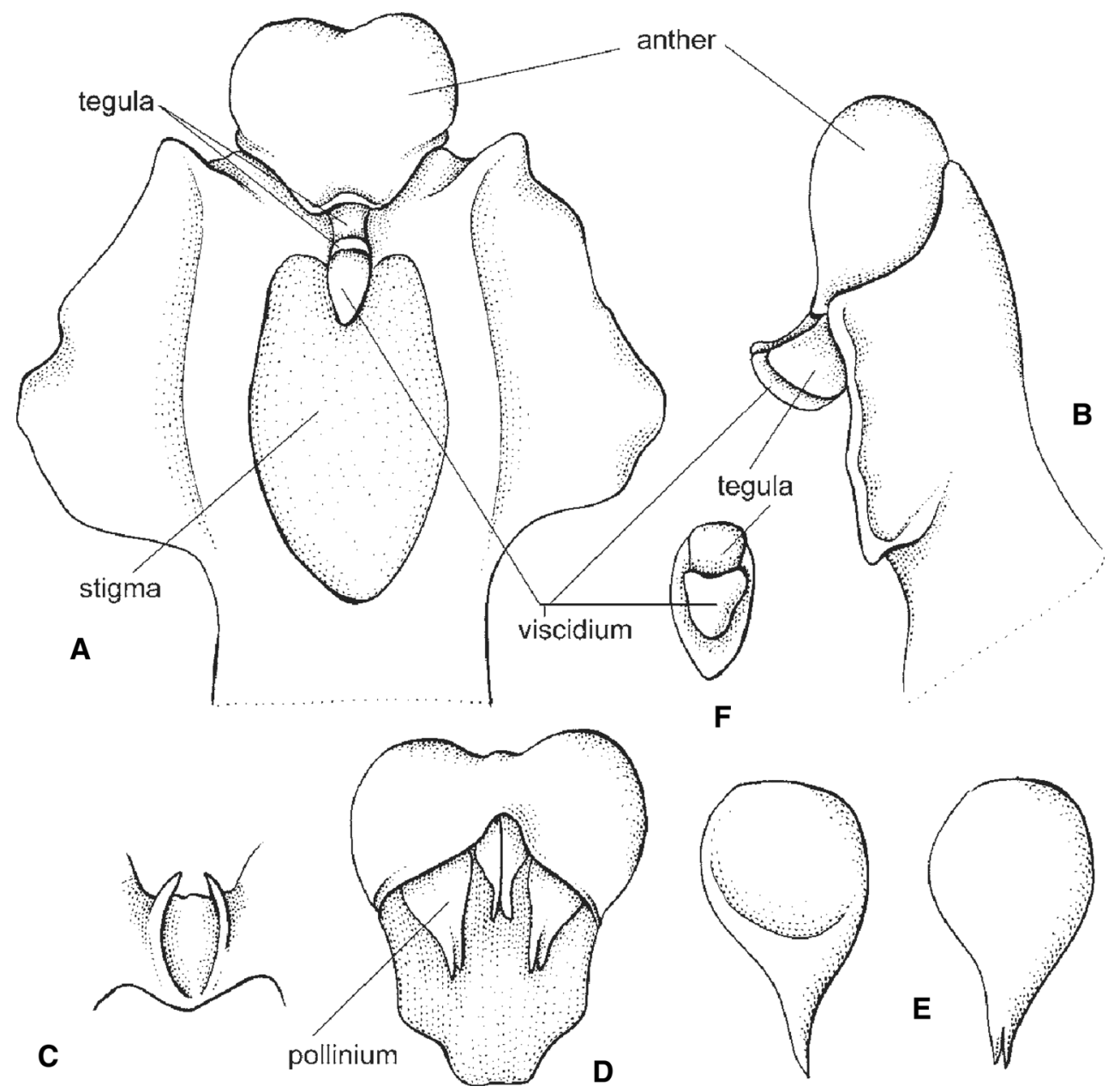


Table 3 Comparative morphology of Plectrophora, Valdiviesoa, Fernandezia and Pachyphyllum

\begin{tabular}{|c|c|c|c|c|}
\hline & Plectrophora & Valdiviesoa & Fernandezia & Pachyphyllum \\
\hline Growth type & Sympodial & Monopodial & Monopodial & Monopodial \\
\hline Flowers & $\begin{array}{l}\text { Medium-sized, campanulate, } \\
\text { spurred }\end{array}$ & $\begin{array}{l}\text { Inconspicuous, } \\
\text { slightly asymmetric, } \\
\text { not spurred }\end{array}$ & $\begin{array}{l}\text { Showy, spreading to } \\
\text { campanulate, not spurred }\end{array}$ & $\begin{array}{l}\text { Inconspicuous, campanulate, } \\
\text { not spurred }\end{array}$ \\
\hline Flower color & $\begin{array}{l}\text { Greenish-white, lip with pale } \\
\text { yellow-orange nectar guides }\end{array}$ & Semitransparent, white & $\begin{array}{l}\text { Red to yellow, orange, or } \\
\text { purple, rarely greenish-white }\end{array}$ & Green to whitish or yellowish \\
\hline Tepals & Sepals forming a tube & $\begin{array}{l}\text { Sepals and petals } \\
\text { similar, not forming } \\
\text { a tube }\end{array}$ & $\begin{array}{l}\text { Sepals and petals similar, not } \\
\text { forming a tube }\end{array}$ & $\begin{array}{l}\text { Sepals and petals similar, } \\
\text { petals often adnate to the } \\
\text { sepals forming part of the cup } \\
\text { of the tube }\end{array}$ \\
\hline Lip & $\begin{array}{l}\text { Forming a spur at the base } \\
\text { within the sepaline spur, } \\
\text { entire, often with sides } \\
\text { embracing the gynostemium }\end{array}$ & $\begin{array}{l}\text { Not spurred, entire, } \\
\text { with obscure callus } \\
\text { below the middle, } \\
\text { basally } \\
\text { asymmetrical, } \\
\text { shallowly saccate. }\end{array}$ & $\begin{array}{l}\text { Usually entire, often flabellate, } \\
\text { Sometimes the base parallel } \\
\text { with the column and the } \\
\text { apex somewhat reflexed, } \\
\text { callus vary between species, } \\
\text { but usually lamellate }\end{array}$ & $\begin{array}{l}\text { Usually entire, sometimes } \\
\text { Somewhat 3-lobate, usually } \\
\text { with a pair of tuberculate } \\
\text { Callii }\end{array}$ \\
\hline $\begin{array}{l}\text { Gynostemium- } \\
\text { column part }\end{array}$ & $\begin{array}{l}\text { ca. } 3 \text { Times longer than anther, } \\
\text { fused basally with lip, with } \\
\text { two prominent, elongate- } \\
\text { rhomboid wings near stigma, } \\
\text { wings erect, thick, irregularly } \\
\text { and shallowly lobed }\end{array}$ & $\begin{array}{l}\text { Broadly winged; } \\
\text { wings basally } \\
\text { connate with the lip } \\
\text { margins forming } \\
\text { spacious sac }\end{array}$ & $\begin{array}{l}\text { As long as anther, broadly } \\
\text { winged, wings thin, close } \\
\text { one to another or even } \\
\text { touching each other in front } \\
\text { of gynostemium }\end{array}$ & $\begin{array}{l}\text { ca. } 3 \text { Times longer than anther, } \\
\text { broadly winged, wings thin, } \\
\text { close one to another or even } \\
\text { touching each other in front } \\
\text { of Gynostemium }\end{array}$ \\
\hline $\begin{array}{l}\text { Gynostemium- } \\
\text { column foot }\end{array}$ & Obscure & Absent & Absent & Obscure \\
\hline $\begin{array}{l}\text { Gynostemium- } \\
\text { clinandrium. }\end{array}$ & Apical clinandrium narrow & $\begin{array}{l}\text { Apical clinandrium } \\
\text { obscure, narrow }\end{array}$ & $\begin{array}{l}\text { Apical clinandrium well- } \\
\text { developed, forming a very } \\
\text { high collar hiding } \\
\text { completely anther, entire or } \\
\text { irregularly denticulate (on } \\
\text { margin }\end{array}$ & $\begin{array}{l}\text { Apical clinandrium well- } \\
\text { developed, forming a very } \\
\text { high collar hiding completely } \\
\text { anther, entire on margin }\end{array}$ \\
\hline $\begin{array}{l}\text { Gynostemium- } \\
\text { anther }\end{array}$ & $\begin{array}{l}\text { Apical, incumbent, rather stiffly } \\
\text { joined with column apex, } \\
\text { ellipsoid, 2-chambered. } \\
\text { Filament } \\
\text { elongate }\end{array}$ & $\begin{array}{l}\text { Thin-walled, motile, } \\
\text { not operculate, } \\
\text { anther partitions } \\
\text { reduced. Filament } \\
\text { digitate, erect }\end{array}$ & $\begin{array}{l}\text { Ventral, incumbent, } \\
\text { operculate, dorsiventrally } \\
\text { compressed, ellipsoid, } \\
\text { 2-chambered }\end{array}$ & $\begin{array}{l}\text { Ventral, incumbent, } \\
\text { operculate, slightly } \\
\text { dorsiventrally compressed, } \\
\text { ellipsoid-obovoid, obscurely } \\
\text { 2-chambered }\end{array}$ \\
\hline $\begin{array}{l}\text { Gynostemium- } \\
\text { pollinia }\end{array}$ & $\begin{array}{l}\text { 2, dorsiventrally compressed, } \\
\text { oblong ellipsoid, Deeply and } \\
\text { unequally cleft at apex, hard. } \\
\text { Connective narrow, thin. }\end{array}$ & $\begin{array}{l}\text { 2, suborbicular- } \\
\text { obovoid, hard, split } \\
\text { at the apex. }\end{array}$ & $\begin{array}{l}\text { 2, slightly dorsiventrally } \\
\text { compressed, obovoid, Hard. } \\
\text { Connective narrow, thin. }\end{array}$ & $\begin{array}{l}\text { 2, slightly dorsiventrally } \\
\text { compressed, obliquely } \\
\text { Obovoid, rather hard. } \\
\text { Connective narrow, thin. }\end{array}$ \\
\hline $\begin{array}{l}\text { Gynostemium- } \\
\text { stigma }\end{array}$ & $\begin{array}{l}\text { Large, transversely elliptic to } \\
\text { elliptic-cordate, deeply } \\
\text { concave }\end{array}$ & $\begin{array}{l}\text { Cordate-obovate in } \\
\text { general outline, } \\
\text { concave, covered by } \\
\text { sticky matter }\end{array}$ & $\begin{array}{l}\text { Small, elliptic, concave, } \\
\text { partially hidden by rostellum }\end{array}$ & $\begin{array}{l}\text { Elliptic to transversely elliptic, } \\
\text { deeply concave }\end{array}$ \\
\hline $\begin{array}{l}\text { Gynostemium- } \\
\text { caudiculae }\end{array}$ & Sticky, amorphous & Sticky, amorphous & $\begin{array}{l}\text { Filiform, longer than pollinia, } \\
\text { sometimes amorphous, } \\
\text { sticky }\end{array}$ & Sticky, amorphous \\
\hline $\begin{array}{l}\text { Gynostemium- } \\
\text { rostellum }\end{array}$ & Dome-like, rounded at apex & $\begin{array}{l}\text { Digitate, curved over } \\
\text { stigmatic surface }\end{array}$ & $\begin{array}{l}\text { Ligulate, pendent, built of } \\
\text { several cell layers }\end{array}$ & $\begin{array}{l}\text { Very short, triangular, rather } \\
\text { fleshy, blunt }\end{array}$ \\
\hline $\begin{array}{l}\text { Gynostemium- } \\
\text { viscidium }\end{array}$ & Single, very small, elliptic, thick & $\begin{array}{l}\text { Triangular-ovate, } \\
\text { lamellar, thin }\end{array}$ & $\begin{array}{l}\text { Single, relatively large, elliptic } \\
\text { to obovate, thin, lamellate }\end{array}$ & $\begin{array}{l}\text { Single, very small, elliptic- } \\
\text { obovate, thin, lamellate }\end{array}$ \\
\hline $\begin{array}{l}\text { Gynostemium- } \\
\text { tegula }\end{array}$ & $\begin{array}{l}\text { Single, oblong linear, thin, } \\
\text { lamellate }\end{array}$ & Filiform, sticky & $\begin{array}{l}\text { Single, linear, elliptic to } \\
\text { obovate, thin, lamellate, } \\
\text { built of cells with inner walls } \\
\text { thickened and outer walls } \\
\text { thin }\end{array}$ & $\begin{array}{l}\text { Single, oblong, small, thin, } \\
\text { lamellate }\end{array}$ \\
\hline
\end{tabular}


The monopodial type of growth, the Oncidium-like flowers, the crenate, prominent clinandrium and basally bifid pollinia prompted Senghas (1995) to establish the separate, monotypic subtribe Raycadencoinae (Fig. 4). The gynostemium of Raycadenco, which is slightly sigmoid, slender, delicate, with the wing-like clinandrium, the short rostellum, the small, oval viscidium and the bifid tegula, corresponds well in its structure to Lockhartia (Fig. 5), but surely not to Pachyphyllinae. The general flower morphology, i.a. free tepals, 3-lobed lip with bifid apical lobe and complicated, lobulate, glandular callus could also suggest the close relation between Lockhartia and Raycadenco. These similarities are probably an effect of independent adaptation to similar pollination systems, as they are in serious conflict with results of molecular outcomes (Neubig et al. 2012) and obvious differences in the structure of vegetative parts between Raycadenco and Lockhartia. In the latter genus leaves are iridiform and stem is sympodial, in contrast to monopodial Raycadenco with dorsiventrally flattened leaves. Hereby, we postulate to maintain a status of separate monogeneric subtribe for Raycadencoinae.

As a conclusion to this discussion, we propose to reject most of the nomenclatural changes proposed by Chase and Whitten (2011) as premature. Until more materials of Pachyphyllum, Fernandezia and related genera are available to study, we postulate to maintain traditional concept of the above-mentioned genera, despite that Fernandezia remains a paraphyletic taxon.

The results of the molecular studies of Pachyphyllineae are inconclusive. With his approach only one transfer proposed by Chase and Whitten (2011), F. breviconnata, should be accepted. This species originally described by Schlechter (1921) as member of Pachyphyllum really belongs to Fernandezia. It is the only species of the genus with white flowers, otherwise similar to other Fernandezia representatives.
Fig. 6 Gynostemium structure of Plectrophora iridifolia. $a$ Gynostemium, side view. $b$ Gynostemium, bottom view. $c$ Rostellum remnant, various views. $d$ Pollinia, various views. $e$ Tegula and viscidium (ter Steege \& al. 36, U)

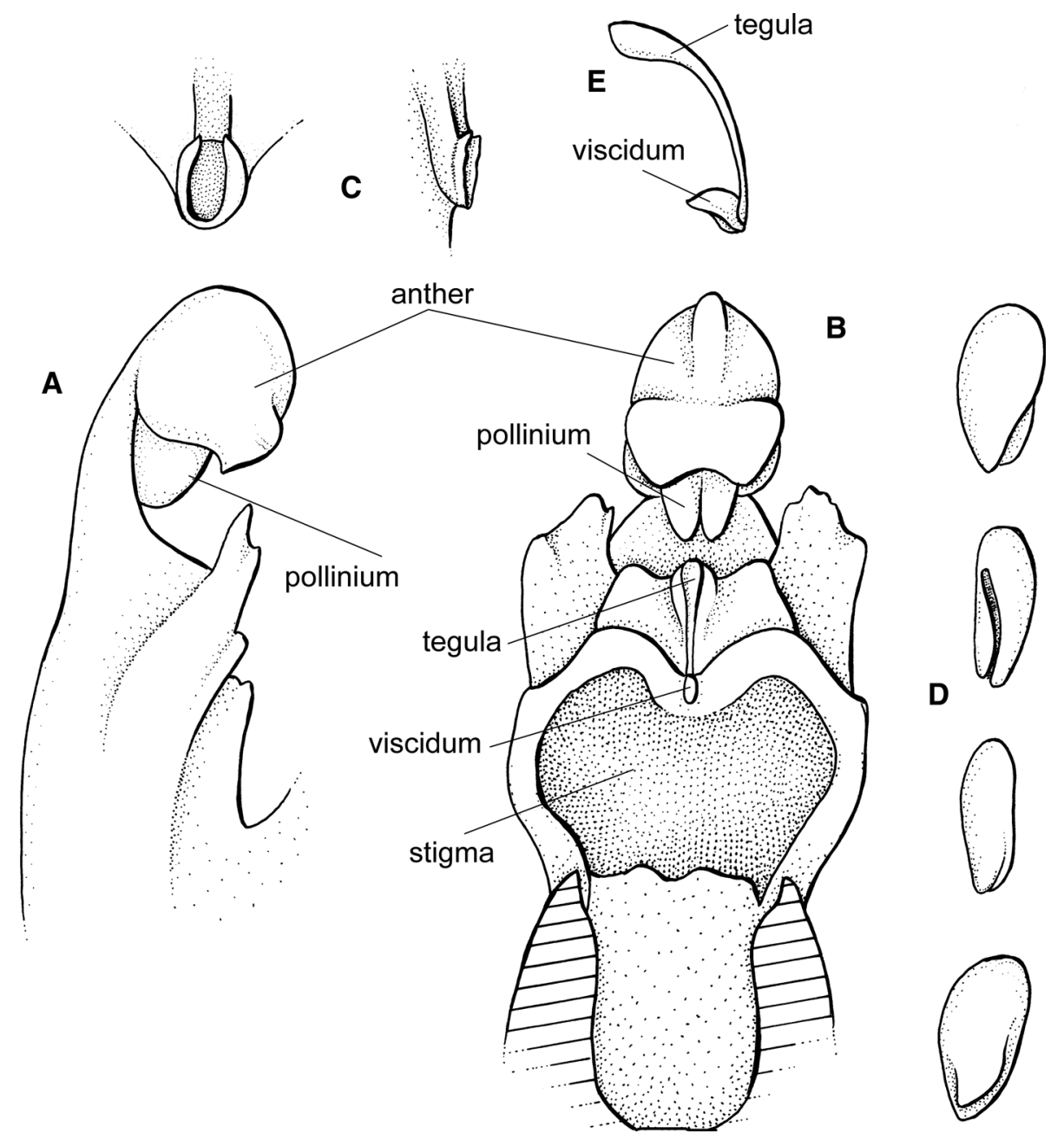




\section{Taxonomic treatment}

During the examination of materials deposited in the National Colombian Herbarium, two distinctive species resembling Pachyphyllum in its habit were found. While in the vegetative structure this taxon resembles other Pachyphyllinae representatives, the gynostemium morphology reminds that of Plectrophora H. Focke (Table 3; Fig. 6). Since neither the flower morphology of the species nor the gynostemium structure fulfils the concept of any known orchid genus, it is described here as new under the name Valdiviesoa.

Subtribe Pachyphyllinae Pfitz., Entw. Nat. Anord. Orchid.: 107. 1887.

Plants monopodial. Inflorescence single- to several-flowered. Clinandrium very tall, hiding anther and rostellum or obscure. Tegula single to double, joined basally, usually narrow and long. Viscidium usually elliptic and small to oblong or triangular-ovate. Pollinia 2, dorsiventrally flattened.

A subtribe of four, mainly Andean genera.

Key to the genera of Pachyphyllinae

1. Flowers relatively large, callus in form of two lamellae running along the lip...Fernandezia
$1 *$ Flowers inconspicuous, callus not as above, if any...2

2. Apical clinandrium relatively obscure, lip callus missing...Valdiviesoa

2* Apical clinandrium well-developed, forming a very high collar hiding completely the anther, callus in form of two digitate or round projections in the lip centre...3

3. Sepals partially connate forming a prominent tube...Orchidotypus

3* Sepals free to the base...Pachyphyllum

Fernandezia Ruiz \& Pav., Fl. Peruv. Prodr.: 123. t. 27. 1794.-GENERITYPE: Fernandezia subbiflora Ruiz \& Pav.

syn. Centropetalum Lindl. 1839.

Plants up to $20 \mathrm{~cm}$ long. Stems concealed by the leaf sheaths. Leaves conduplicate, distichous, articulate. Inflorescence single-flowered or a fascicle of few, showy, red to yellow, orange, or purple flowers, very rarely white. Perianth parts free. Sepals usually smaller than petals, all tepals subsimilar. Lip similar to tepals, rarely flabellate. Gynostemium slender, erect, rather delicate, prominently stalked. Column part as long as the anther, broadly winged, wings thin, close one to another or even touching each other in front of the stigma. Column foot absent. Anther ventral,
Fig. 7 A Fernandezia lanceolata-dissected perianth (redrawn from Dunsterville and Garay 1979). B Fernandezia ionanthera (photo: A. Zöllig)

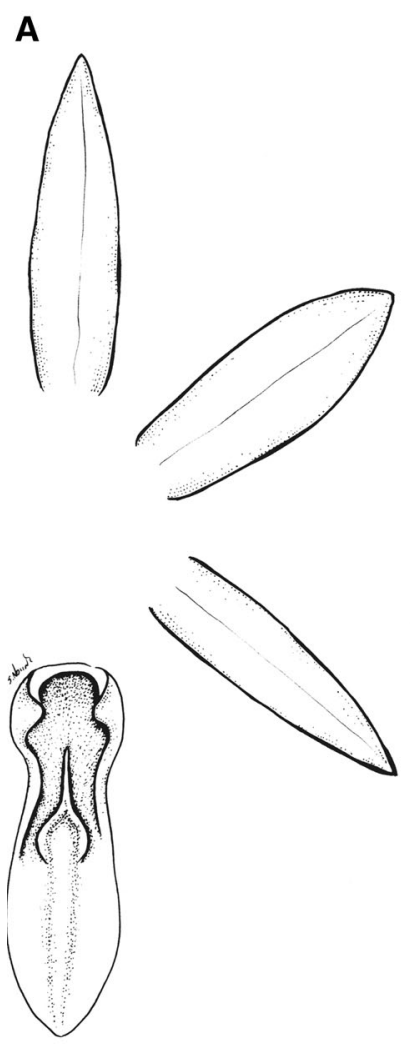


incumbent, operculate, dorsiventrally compressed, ellipsoid, 2-chambered. Connective narrow, thin. Pollinia 2, slightly dorsiventrally compressed, obovoid, hard. Caudiculae filiform, longer than pollinia, sometimes amorphous, sticky. Apical clinandrium well-developed, forming a very high collar hiding completely the anther, entire or irregularly denticulate on margin. Stigma small, elliptic, concave, partially hidden by rostellum. Rostellum ligulate, pendent, built of several cell layers. Viscidium single, relatively large, elliptic to obovate, thin, lamellate, built of two layers of cells: the inner one very stiff and thin, formed of cells with thickened walls, the outer one thicker formed of thin-walled cells. Tegula single, linear, elliptic to obovate, thin, lamellate, built of cells with inner walls thickened and outer walls thin. Rostellum remnant ligulate, canaliculate on the upper surface, very shortly bilobed at the apex (Figs. 1, 7).
The genus embraces about 11 species distributed from Peru to Costa Rica. Fernandezia species grow in wet Andean forest or open paramo vegetation. They occurrence was reported from the altitudes of 2,100-3,300 m.

The two subgenera of Fernandezia may be distinguished as follows:

Pollinarium with two separated tegulae...subgen.

\section{Fernandezia}

Pollinarium with a single tegula...subgen. Nasonia

Pachyphyllum Kunth in Humb., Bonpl. \& Kunth, Nov. Gen. Sp. Pl. 338: t.77. 1816.-GENERITYPE: Pachyphyllum distichum Kunth.

Terrestrial or epiphytic plants. Pseudobulbs absent. Stems erect, creeping or pendulous, concealed by leaf sheaths. Leaves 8-30, conduplicate, fleshy, articulate, sometimes deciduous. Inflorescences 1-50, lateral, sparsely branched, usually few-flowered. Flowers resupinate,
Fig. 8 A Pachyphyllum dalstroemii-dissected perianth (redrawn from Dodson 1997). B Pachyphyllum crystallinum (photo: M. Kolanowska)
Fig. 9 A Orchidotypus hispidulus - dissected perianth (redrawn from Mora-Retana and Atwood 1992). B Orchidotypus hispidulus (photo: S. Vieira)
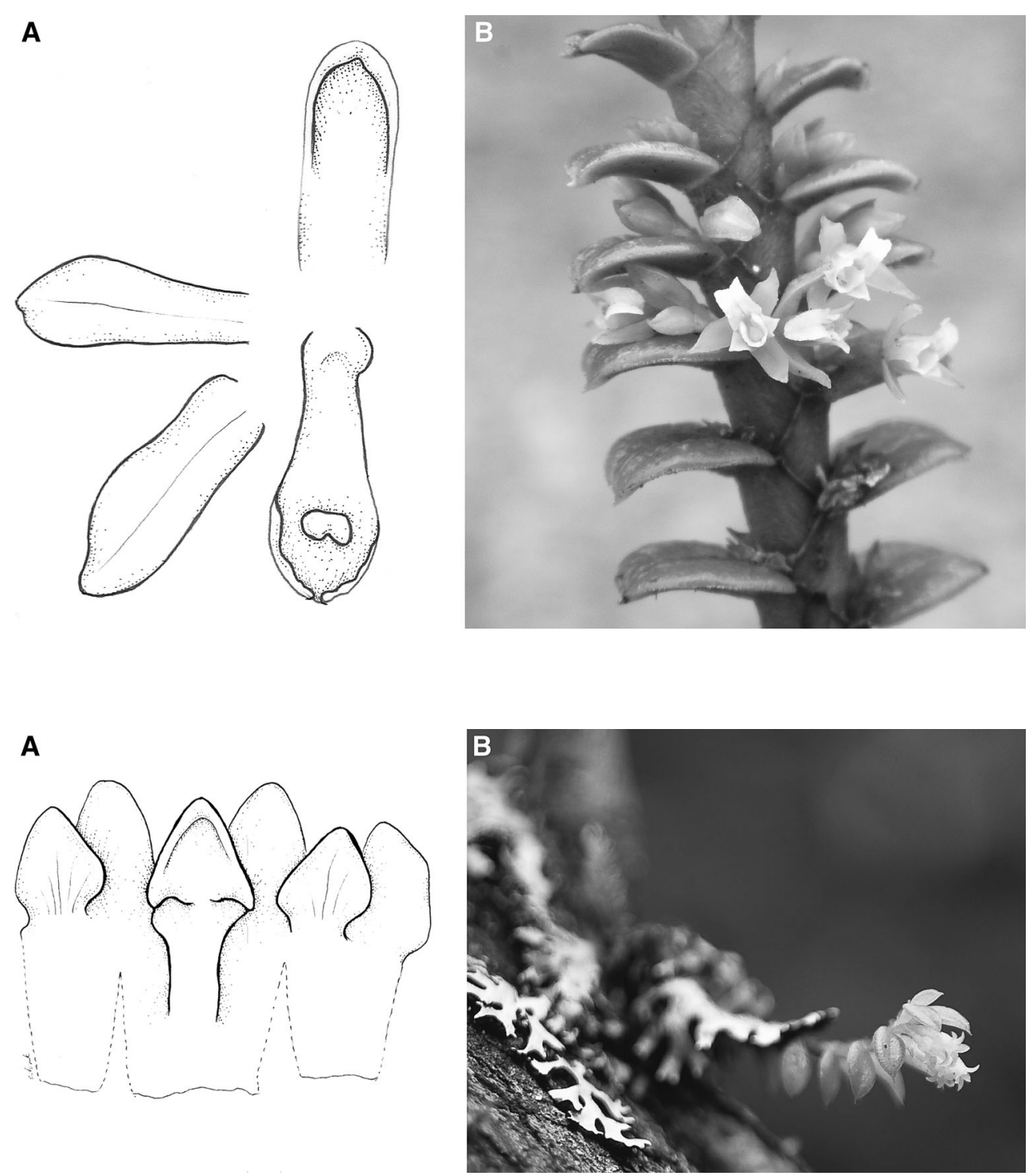
Fig. 10 Gynostemium structure of Valdiviesoa.

A-C gynostemium, bottom view; D pollinarium, various views
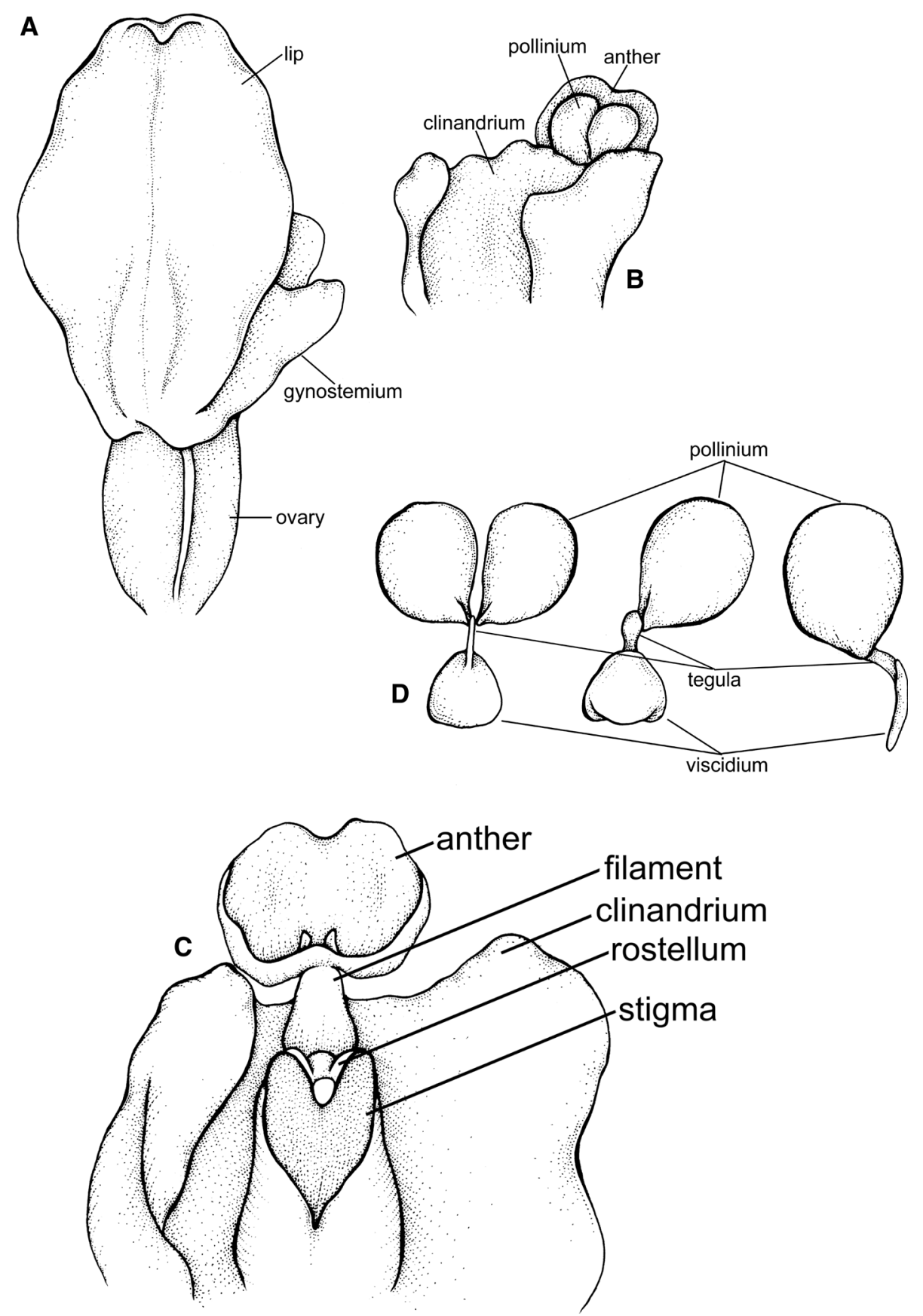

inconspicuous, green to whitish or yellowish. Floral bracts shorter than pedicel. Ovary glabrous. Tepals free, subsimilar. Lip simple to obscurely 3-lobed, callus a pair of digitate projections. Gynostemium sessile, rather short, gently arched, delicate. Column part ca. 3 times longer than anther, broadly winged, wings thin, close one to another or even touching each other in front of the receptive surface. Column foot obscure. Anther ventral, incumbent, operculate, slightly dorsiventrally compressed, ellipsoid-obovoid, obscurely 2-chambered. Pollinia 2, slightly dorsiventrally compressed, obliquely obovoid, rather hard. Caudiculae amorphous, sticky. Apical clinandrium well-developed, forming a very high collar hiding completely the anther, entire on margin. Stigma elliptic to transversely elliptic, deeply concave. Rostellum very short, triangular, rather fleshy, blunt. Viscidium single, very small, elliptic-obovate, thin, lamellate. Tegula single, oblong, small, thin, lamellate. Rostellum remnant very shortly digitate, obscurely bilobed at the apex (Figs. 1, 8). 

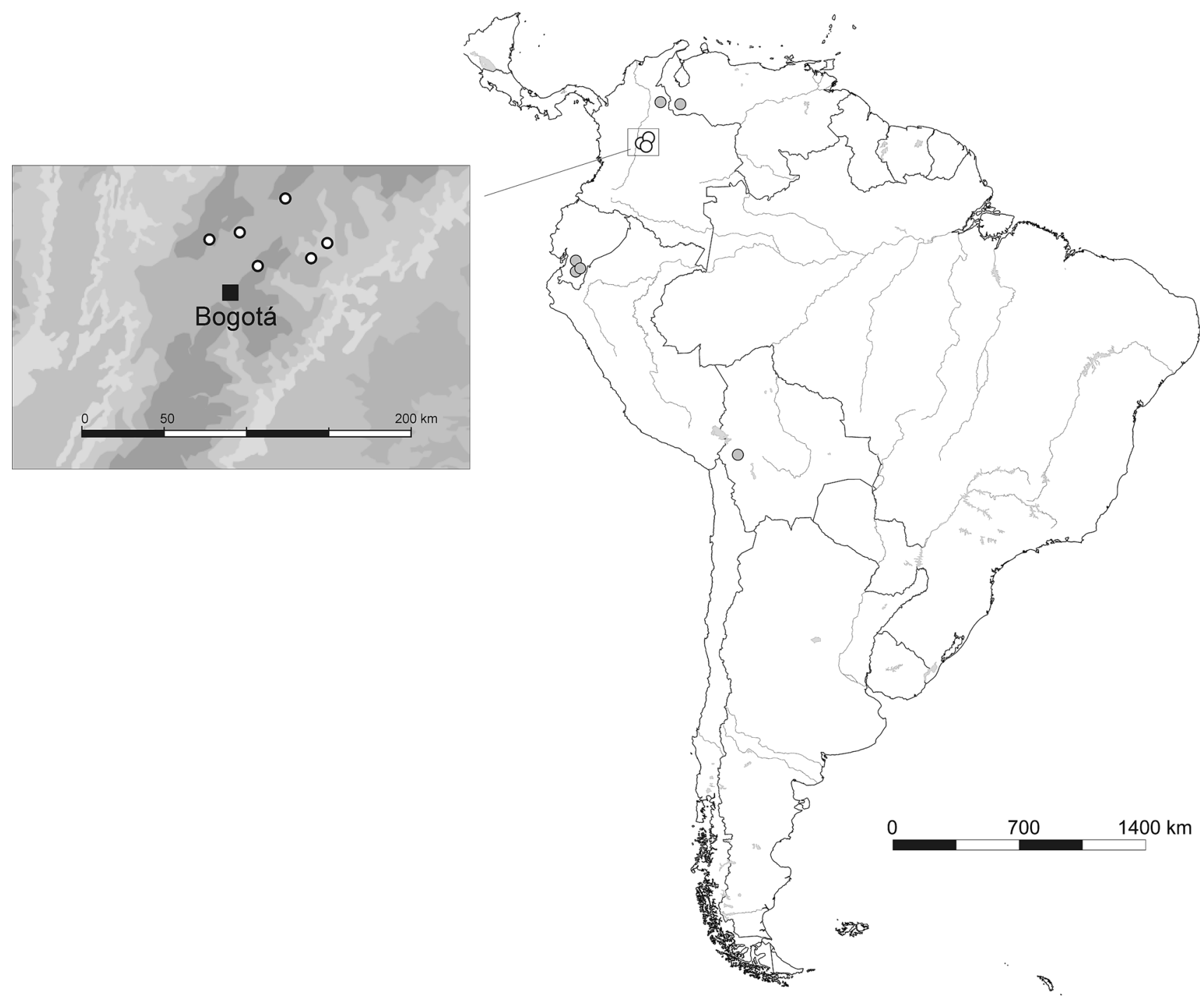

Fig. 11 Distribution of Valdiviesoa debedoutii (white circles) and V. tortuosa (gray circles)

The genus embraces about 40 species described so far distributed from Bolivia and Peru to Costa Rica. Pachyphyllum species grow in wet montane forest or open páramo vegetation. They occur at high elevation of about 2,800-4,000 m.

Orchidotypus Kraenzl., Bot. Jahrb. Syst. 37: 383. 1906.-GENERITYPE: Orchidotypus muscoides Kraenzl.

Small or tiny, pendent epiphytes or terrestrials. Stems weak, branching only at the base, concealed by the leaf sheaths. Leaves fleshy, distichous, ciliate-dentate on margins, blades falcate-lanceolate to elliptic, acute, diminishing in size apically, often twisted basally. Inflorescence axillary, 1-3-flowered, shorter than the leaves. Flowers minute. Perianth parts connate into prominent tube. Lip similar to the petals, with claw united to the perianth tube, and a pair of rounded calli on each side below the disk base. Gynostemium sessile, short, bent back or gently arched, delicate. Column part ca. twice as long as anther, broadly winged, wings thin, rather close to each other in front of the gynostemium. Column foot absent. Anther ventral, incumbent, motile, dorsiventrally compressed, ellipsoid-cordate, obscurely 2-chambered. Connective narrow, thin. Pollinia 2, slightly dorsiventrally compressed, obovoid to clavate, rather hard. Caudiculae amorphous, sticky. Apical clinandrium well-developed, forming a very high collar hiding completely the anther, entire or irregularly denticulate on margin. Stigma elliptic, concave. Rostellum very short. Viscidium single, relatively large, ellipticobovate, thin, lamellate. Tegula single, linear, very small, thin, lamellate. Rostellum remnant very shortly bilobed at the apex (Figs. 1, 9). 


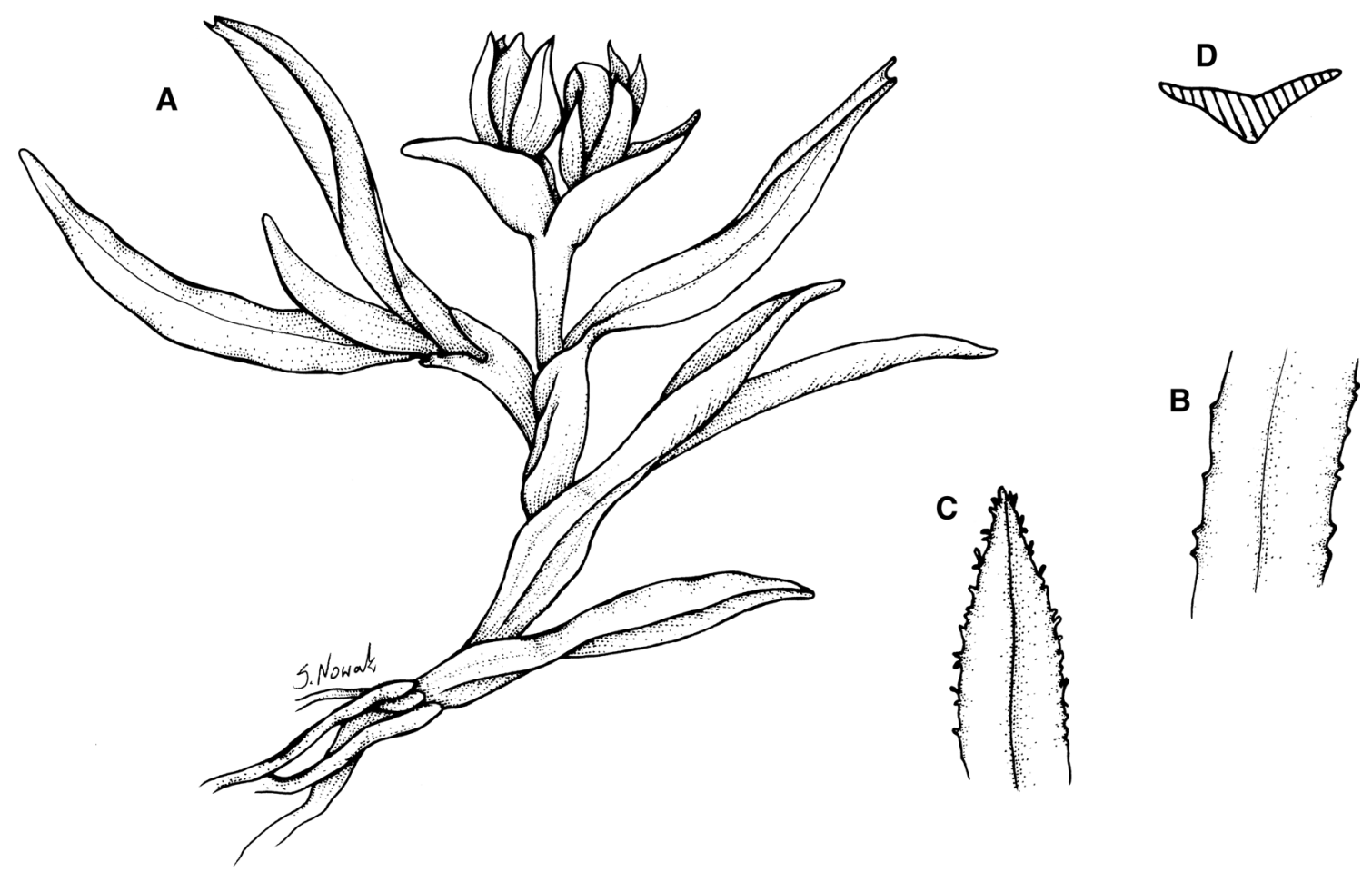

Fig. 12 Valdiviesoa debedoutii. A Habit. B Details of leaf margin. C Leaf apex. D Leaf section

The genus embraces about seven species distributed from Peru to Venezuela. The occurrence of Orchidotypus was reported from the altitudes of $2,500-3,600 \mathrm{~m}$. The species are usually found in high-Andean forest. According to Senghas (1995) the genus is characterized by the presence of two elongate stipes (caudiculae?), but it was not confirmed during the studies.

Valdiviesoa Szlach. \& Kolan., gen. nov.-GENERITYPE: Valdiviesoa debedoutii (P. Ortiz) Szlach. \& Kolan [=Pachyphyllum debedoutii P. Ortiz].

The genus appears to be related to Pachyphyllum and Fernandezia. Plants monopodial, small. Leaves thick, coriaceous, basally twisted. Inflorescence lateral, subcapitate. Flowers small, inconspicuous. Lip connate with the base of gynostemium forming a sac. Gynostemium broadly alate. Apical clinandrium obscure, narrow. Anther motile, not operculate. Pollinia 2, suborbicular-globose, tegula single, filiform, viscidium lamellar, thin.

Monopodial epiphytic plants. Leaves several per stem, linear-lanceolate, acute, thick, basally twisted. Inflorescence lateral, erect, subcapitate, 2-4-flowered. Flowers sessile, non-resupinate, erect, slightly asymmetric, semitransparent, white. Dorsal sepal oblong-elliptic to ligulate, obtuse. Petals obliquely oblong-elliptic, acute at apex. Lateral sepals oblong-ligulate, acute. Lip ovate to broadly ovate, truncate at apex, shortly apiculate, with obscure callus below the middle, basally asymmetrical, shallowly saccate. Gynostemium erect, broadly winged; wings basally connate with the lip margins forming spacious sac. Filament digitate, erect. Anther thin-walled, motile, not operculate, anther partitions reduced. Rostellum digitate, curved over stigmatic surface. Stigma cordate-obovate in general outline, concave, covered by sticky matter. Pollinarium $0.4 \mathrm{~mm}$ long. Pollinia 2, suborbicular-obovoid, hard, split at the apex. Tegula filiform, sticky. Viscidium triangular-ovate, lamellar, thin (Fig. 10).

Etymology: The generic name is dedicated to Pedro Ortiz Valdivieso, an eminent Colombian orchidologist (1926-2012).

Habitat and Ecology: Valdiviesoa was found growing epiphytically in Andean cloud forest and subparamo at the altitudes between 2,400 and $3,500 \mathrm{~m}$. Valdiviesoa representatives are almost indistinguishable in their habit from the small-sized Orchidotypus species. The leaves in both genera are relatively soft in comparison to stiff foliation observed in Pachyphyllum species. Similar habit, representatives of Orchidotypus are easily distinguished from Valdiviesoa in the connation of their tepals and lip into a conspicuous tube and the presence of the prominent apical clinandrium. Moreover, tepals of $\mathrm{Val}$ diviesoa are ciliolate or papillate, at least in the apical part, while all perianth segments of Orchidotypus representatives are entire, glabrous. Both $O$. hispidulus and 

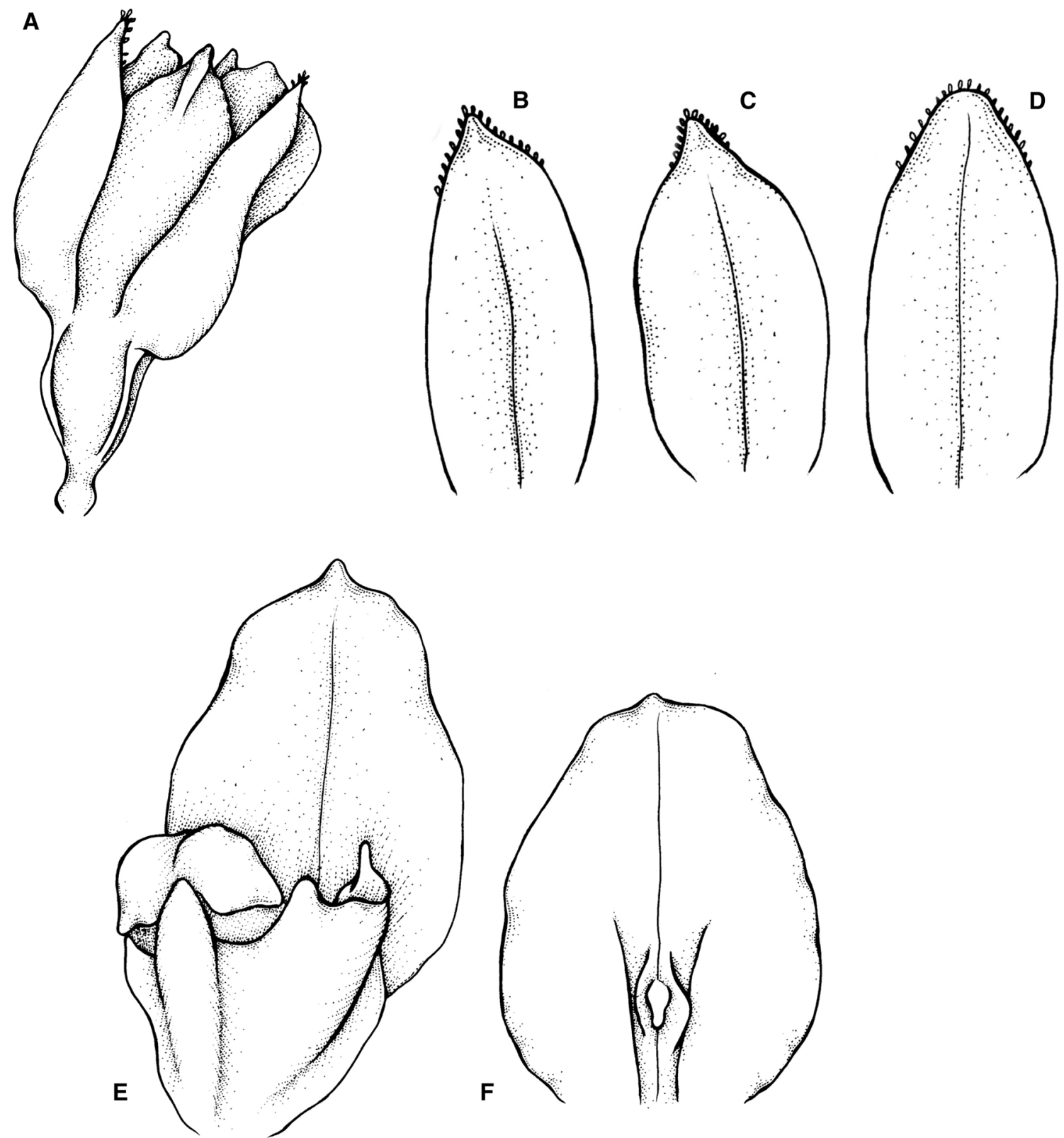

Fig. 13 Valdiviesoa debedoutii. A Flower. B Petal. C Lateral sepal. D Dorsal sepal. E Gynostemium and lip. F Lip

O. schultesii were found in the same region of Cundinamarca where the type specimen of $V$. debedoutii was collected.

Distribution: The genus includes only two species. While the geographic range of $V$. tortuosa extends from Bolivia to the border between Colombia and Venezuela, $V$. debedoutii is known so far exclusively from Colombia (Fig. 11).

Key to the species of Valdiviesoa

Dorsal sepal narrowly ovate, subobtuse, lip ovate with an obtuse apicule...V. debedoutii
Dorsal sepal ovate-lanceolate, acute, lip elliptic-suborbicular, rounded...V. tortuosa

Valdiviesoa debedoutii (P. Ortiz) Szlach. \& Kolan., comb. nov.

Basionym: Pachyphyllum debedoutii P.Ortiz, Orquideología 13: 13. 2009. Fernandezia debedoutii (P. Ortiz) M. W. Chase, Phytotaxa 20: 30. 2011.-TYPE: COLOMBIA. Cundinamarca. Guasca, Hacienda La Esperanza, Alt. 2,950 m. Ortiz P., de Bedout R. \& Alvarez L. E. 1298 (holotype: HPUJ!) (Figs. 12, 13, 14). 


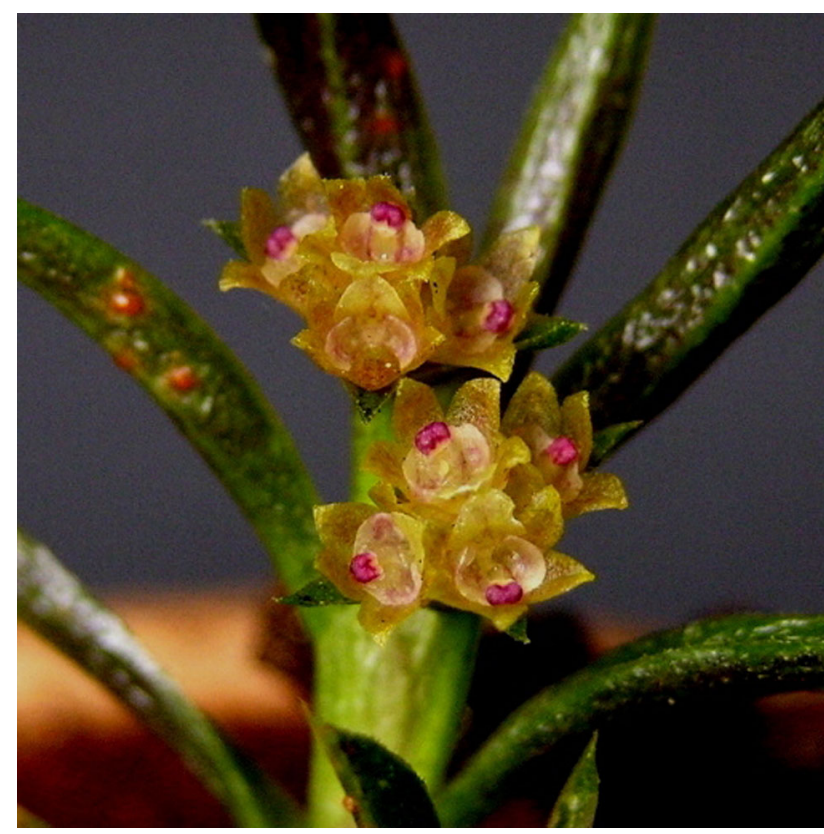

Fig. 14 Valdiviesoa debedoutii-inflorescence (photo: R. de Bedout Herrera)

Representative Specimens: COLOMBIA. Boyacá. Carretera de Guateque a Santa Maria. Entre Santa Maria y Piedra Campana, Alt. 800-1,200 m, 10-12 Mar 1960, Garcia Barriga 17209a (COL!). Cundinamarca. [Distr. Capital Bogotá]. Usaquén. Matorrales y bisques, Alt. 2,900 m. Epifita. Periantio verdoso claro, con manchitas pardusco-violaceas. Labelo verde claro, con 2 callos amarillos, Schneider 196/1 (COL!). Mpio. La Calera. Carretera via Club la calima. Hierba epifita, inconspicua debido a su pequeno tamano. Sepalos y petalos transparentosos, blanco rosados, labelo blanco, antera morada. Entre 0.5 y $2 \mathrm{~m} \mathrm{de}$ altura del suelo, formando pequenas poblaciones. Arboles solitaries en un potrero. $04^{\circ} 41^{\prime} 02^{\prime \prime} \mathrm{N} 73^{\circ} 58^{\prime} 24^{\prime \prime} \mathrm{W}$, Alt. 3,027 m, 15 Apr 2006, R. Arevalo, A. Barona \& J. Chacon 539 (COL!). Mpio. Chocontá. El Sisga. Carretera a Chocontá. A $2 \mathrm{~km}$ al $\mathrm{N}$ del Puente, Alt. 2,800 m. 12 Oct 1972. Epifita sobre arboles. Petalos verde con manchitas carmelitas, sepalos del mismo color, labelo Rosado con manchas rojas, H. Garcia Barriga 20356 (COL!); El Sisga. Chocontá, parte alta de La Represa, Alt. 2,700-2,800 m. Muy pequena, de caliz ferrugineo y petalos amarillos, 14 Jan 1962, H. Garcia Barriga 17383 (COL!). Mpio. Guasca.
El Salitre, Reserva Biologica El Encenillo, en la parcela no 3, cercana a el sender Julio Carrizosa. Bosque nublado andino de 30 anos de regeneracion muy denso con dosel de $8 \mathrm{~m}$. Orquidea pequena epifita, flores crema-transparentes, anteras moradas, stigma naranja, Alt. 2,900-3,200 m, 28 Mar 2009, Rodrigo Camara Leret 224 (COL, COL-spirit); Vereda Potreritos, canon del rio Tunjo. Epifito, poco abundante, perianto verde claro, labelo tenido de morado, Alt. 2,480 m, 21 Jun 1989, E. Linares \& R. Sanchez 2818 (COL! 440290). Mpio. Subachoque. Entre La Pradera y Zipaquira, finca Pie de Loma. En un bosque con Wienmannia, Oreopanax, Gaiadendron, Diplostephium, Myrsine, Cavendishia, etc. Desde de 6-8 $\mathrm{m}$ de altura, Alt. 2,900 m, 29 Mar 2003, M. Hernandez Schmidt 1133 (COL!). Mpio. Zipaquirá. El Gaque, Alt. 3,150 m, 15 Jul 1942, Camargo \& Huertas 1104 (COL!).

Valdiviesoa tortuosa (Foldats) Szlach. \& Kolan., comb. nov.

Basionym: Pachyphyllum tortuosum Foldats, Bol. Soc. Venez. Ci. Nat. 28: 252. 1969. Fernandezia tortuosa (Foldats) M.W. Chase, Phytotaxa 20: 31. 2011, syn. nov.-TYPE: Venezuela. Edo Tachira: Rio Quinimari. Quebrada Las Copas, Alt. 2,600-2,630 m. G. C. K. Dunsterville \& E. Dunsterville 90 (Holotype: VEN; Isotype: K) (Fig. 15).

Representative Specimens: BOLIVIA. Department. La Paz. Prov. Nor Yungas. Senda Chojllapata, poco después de la torre de energía eléctrica. $16^{\circ} 17^{\prime} \mathrm{S} 067^{\circ} 53^{\prime} \mathrm{W}$, Alt. 3,500 m, I. Jiménez 5280 (LPB), PN-ANMI Cotapata, sendero Sillutinkara. $16^{\circ} 17^{\prime} \mathrm{S} 067^{\circ} 53^{\prime} \mathrm{W}$, Alt. $3,400 \mathrm{~m}, I$. Jiménez 4079 (LPB). COLOMBIA. Department. Norte de Santander. Below the Paramo de Jurisdicciones. Epiphytic in cloud forest. Flowers yellow; anther red, Alt. 3,150 m, 10 May 1984, C.A. Luer et al. 10235 (MO). ECUADOR. Prov. Azuay. Cuenca-Molleturo, Alt. 2,700 m, 14 Jul 1982, C. H. Dodson \& A. Embree 13345 (SEL); Prov. Loja. Parque Nacional Podocarpus. E. of Nudo de Cajanuma, just N. of Centro de Información Sample plot site. Epiphyte on twigs. Flowers white. $04^{\circ} 05^{\prime} \mathrm{S} 079^{\circ} 10^{\prime} \mathrm{W}$, Alt. $2,900 \mathrm{~m}, 20$ Sep-16 Nov 1989, A. Bøgh Pedersen 47947 (AAU, MO); Prov. ZamoraChinchipe. Yangana-Valladolid, Alt. 3,000 m, 23 Mar 1985, A. Hirtz 2301 (RPSC), Loja-Zamora, Alt. 2,750 m, 18 Nov 1961, C. H. Dodson \& L.B. Thien 1331 (SEL). 

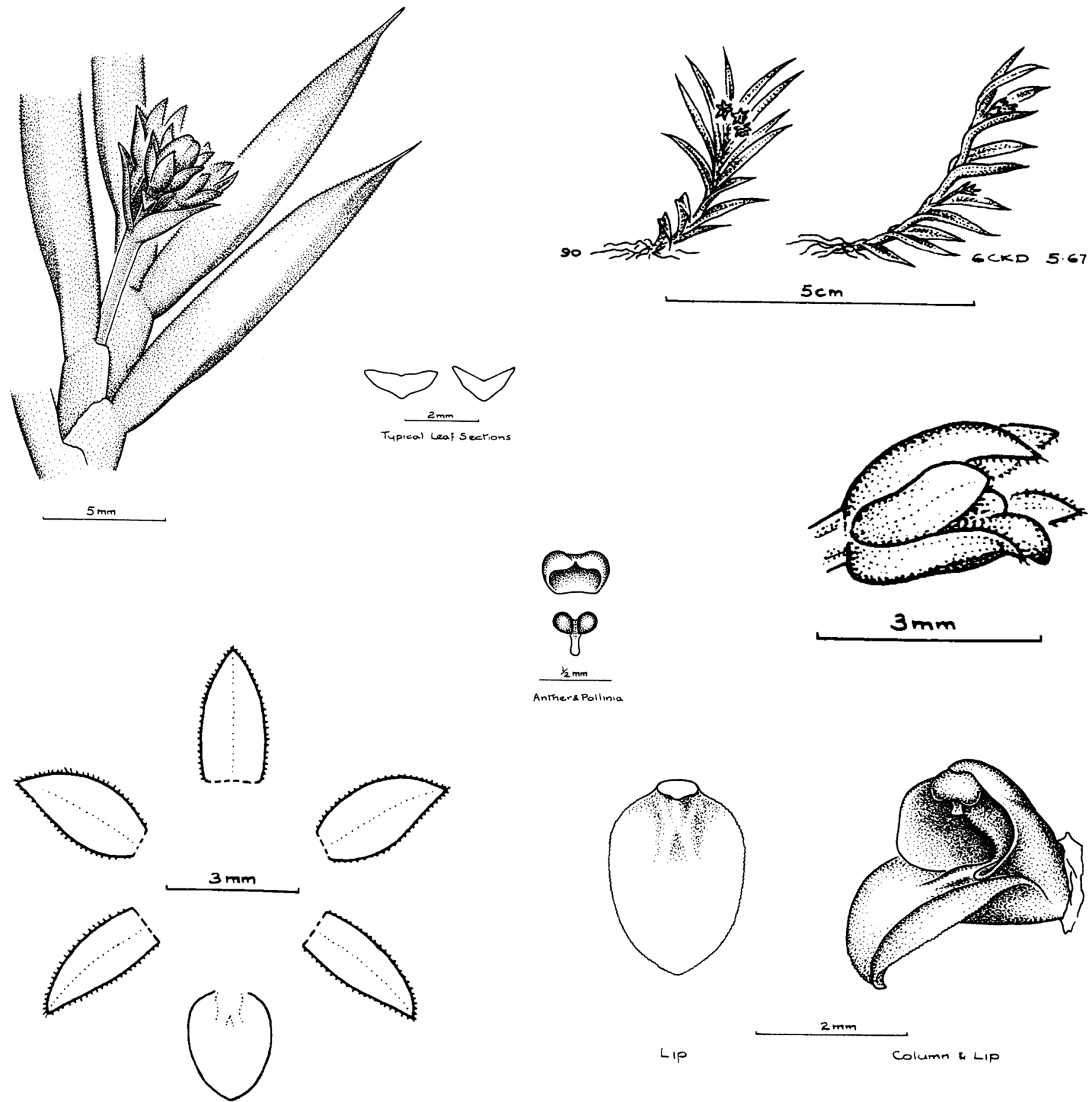
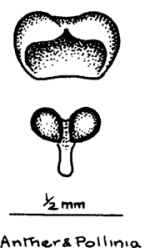
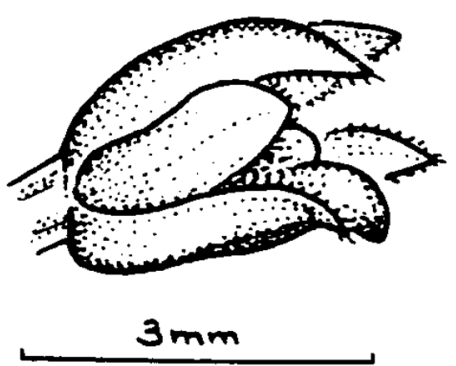
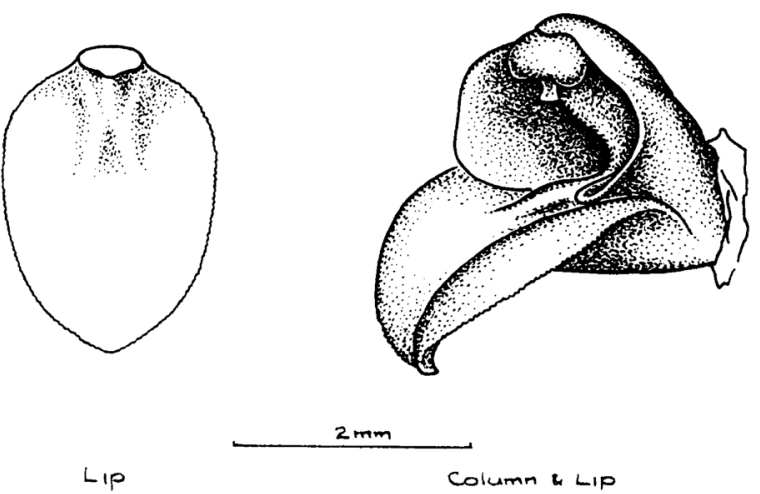

Fig. 15 Valdiviesoa tortuosa (reproduced from Dunsterville and Garay 1976, with kind permission of AMES)

VENEZUELA. Edo Tachira. Rio Quinimari. Quebrada Las Copas, Alt. 2,600-2,630 m, G. C. K. Dunsterville \& E. Dunsterville 90 (K, VEN).

Acknowledgments The authors are grateful to the Curators and staff of the cited herbaria for their assistance during the visits in the herbarium and for making specimens available on loan. We wish to thank the anonymous referees whose comments contributed considerably to the improvement of the manuscript and Sławomir Nowak for his help in preparing the illustrations. We are grateful to the Swiss
Orchid Foundation and their collaborators for providing photographs and to Dr G. A. Romero-González for his kind permission to reproduce Dunsterville's illustration. The paper is a part of a project supported with a grant from the Polish Ministry of Science and Higher Education (8124/B/PO1/2011/40) and Synthesys grants (AT-TAF2483, GB-TAF-2445).

Open Access This article is distributed under the terms of the Creative Commons Attribution License which permits any use, distribution, and reproduction in any medium, provided the original author(s) and the source are credited. 


\section{References}

Chase MW (2009) Subtribe Oncidiinae. In: Pridgeon AM, Chase MW, Cribb PJ, Rasmussen FN (eds) Genera Orchidacearum, vol 5. Epidendroideae (part two). Oxford University Press, Oxford, pp 211-394

Chase MW, Whitten WM (2011) Further taxonomic transfers in Oncidiinae (Orchidaceae). Phytotaxa 20:26-32

Chase MW, Cameron KM, Barrett RL, Freudenstein JV (2003) DNA data and Orchidaceae systematics: a new phylogenetic classification. In: Dixon KW, Kell SP, Barrett RL, Cribb PJ (eds) Orchid conservation. Natural History Publications, Kota Kinabalu, pp 69-89

Christenson EA (2008) A synopsis of Pachyphyllum (Orchidaceae). J Bot Res Inst Texas 2(1):285-289

Dodson CH (1989) Raycadenco ecuadorensis. In: Dodson $\mathrm{CH}$, Dodson PM (eds) Icon Pl Trop 2(6):pl 0577

Dodson CH (1997) New Orchid species from Ecuador 5. Orquideologia 20(3):271-279

Dressler RL (1971) Nomenclatural notes on the Orchidaceae V. Phytologia 21:440-443

Dressler RL (1981) The Orchids: natural history and classification. Harvard University Press, Cambridge

Dressler RL (2003) Orchidaceae. In: Hammel BE, Grayum MH, Herrera C, Zamora N (eds) Manual de Plantas de Costa Rica. vol. 3. Monogr Syst Bot Mo Bot Gard 93:1-595

Dressler RL, Dodson CH (1960) Classification and phylogeny in the Orchidaceae. Ann Missouri Bot Gard 47:25-68

Dunsterville GCK, Garay LA (1976) Venezuelan orchids illustrated, vol 6. Andre Deutsch, London

Dunsterville GCK, Garay LA (1979) Orchids of Venezuela, an Illustrated Field Guide. Botanical Museum of Harvard University, Cambridge, Massachusetts

Garay LA (1972) On the systematics of the monopodial orchids I. Bot Mus Lealf Harv Univ 23:149-212

Garay LA, Dunsterville GCK (1972) Venezuelan orchids illustrated 5. Andre Deutsch, London
Lindley J (1824) Sarcanthus. Bot Reg 9: p 875

Lindley J (1826) Collectanea botanica, or, Figures and botanical illustrations of rare and curious exotic plants. R. and A. Taylor, London

Lindley J (1838) Sertum Orchidaceum, a wreath of the most beautiful Orchidaceous flowers. James Ridgeway, London

Lindley J (1844) Orchidaceae Loxenses. In: Bentham G (ed) Plantas Hartwegianas imprimis Mexicanas adjectis nunnullis Grahamianis enumerat novasque describit. Part 2. Plantarum Hartwegianarum. George Bentham, London, pp 149-156

Mora-Retana DE, Atwood JT (1992) Pachyphyllum hispidulum. In: Atwood JT (ed) Orchids of Costa Rica. Icon Pl Trop 15:pl 1476

Neubig KM, Whitten WM, Williams NH, Blanco MA, Endara L, Burleigh JG, Silvera K, Cushman JC, Chase MW (2012) Generic recircumscriptions of Oncidiinae (Orchidaceae: Cymbidieae) based on maximum likelihood analysis of combined DNA datasets. Bot J Linean Soc 168:117-146

Pfitzer E (1887) Orchidaceae. In: Engler A, Prantl KE (eds) Die natürlichen Pflanzenfamilien. Wilhelm Engelmann, Leipzig, pp 52-224

Schlechter R (1915) Die Orchideen:ihre Beschreibung, Kultur und Züchtung. Handbuch für Orchideenliebhaber, Züchter und Botaniker. P. Parey, Berlin

Schlechter R (1921) Orchideenfloren der Suedamerikanischen Kordillerenstaaten, Peru. Beschreibungen neuer Arten. Feddes Repert Spec Nov Regni Veg Beih 9:41-118

Schlechter R (1929) Figuren-Atlas zu den Orchideenfloren der südamerikanischen Kordillerenstaaten. Repert Sp Nov Regni Veg Beih 57:1-142

Schweinfurth C (1961) Orchidaceae, Orchids of Peru. Fieldiana, Bot 30(4):787-1005

Senghas K (1995) 749.Chytroglossa-770. Sutrina. Orchideen (Schlechter) (ed 3), Vol. 1B, Lieferung 31:1905-1976

Szlachetko DL (1995) Systema Orchidalium. Fragm Florist Geobot Pol Suppl. 3:1-137

Szlachetko DL, Mytnik-Ejsmont J (2009) Gynostemia Orchidalium IV. Acta Bot Fenn 180:1-313 